\title{
COVID-19 vaccine - technical aspects of vaccination
}

\author{
Szczepionka przeciw COVID-19 - techniczne aspekty wykonania szczepienia
}

\section{Marzena Jaciubek ${ }^{\circledR}$, Karolina Prasek ${ }^{\circledR}$}

Zakład Podstaw Pielęgniarstwa, Wydział Nauki o Zdrowiu,Warszawski Uniwersytet Medyczny/ Department of Basic Nursing, Faculty of Health Sciences, Medical University of Warsaw

Słowa kluczowe:

\section{SZCZEPIONKA PRZECIW COVID-19 - TECHNICZNE ASPEKTYY WYKONANIA SZCZEPIENIA}

Wprowadzenie. Na całym świecie rozpoczęła się walka z wirusem SARS-CoV-2 wywołującym COVID-19. Możliwe jest to dzięki bardzo szybkiemu opracowaniu i zbadaniu preparatów leczniczych o tak wysokiej skuteczności (94-95\%), które mogą być podawane dorosłym pacjentom w celu masowego uodpornienia. Wyzwaniem pozostaje wyprodukowanie i dostarczenie tak ogromnej liczby szczepionek, natomiast niewątpliwie ważnym aspektem jest bezpieczne i zgodne z zasadami podanie preparatów leczniczych. Osobami aktualnie uprawnionymi do podawania szczepionek przeciw COVID-19 są lekarze, felczerzy, pielęgniarki, położne, ratownicy medyczni i higienistki szkolne. Natomiast pojawia się wiele sprzecznych informacji jak podawać szczepionkę przeciw COVID-19? Ujmować skórę w fałd czy rozciągać? Aspirować czy nie?

Podsumowanie. Pielęgniarki od lat wykonują szczepienia ochronne, mając odpowiednie wykształcenie i doświadczenie w tej kwestii. Aktualnie dostępne szczepionki przeciw COVID-19 podawane są domięśniowo w mięsień naramienny. Zalecenia rekomendują podanie szczepionki w wyznaczone miejsce pod kątem 90 stopni jednocześnie rozciągając skórę palcem wskazującym i kciukiem, bez aspiracji po wkłuciu. Niniejszy artykuł przedstawia podstawowe informacje dotyczące szczepionki oraz opracowany przez autorów algorytm podania szczepionki przeciw COVID-19.

koronawirus, szczepienie, pielęgniarka

\section{ABSTRACT COVID-19 VACCINE - TECHNICAL ASPECTS OF VACCINATION}

Introduction. All over the world the fight against the SARS-CoV-2 virus, which causes COVID-19, has already begun. Very quick development and testing of medicinal preparations with such a high efficiency (94-95\%), which can be administered to adult patients for mass immunization, makes this fight possible. The production and delivery of a huge number of vaccines remains a challenge, but an undoubtedly important aspect is the safe and compliant administration of medicinal preparations. People currently authorized to administer COVID-19 vaccines are doctors, paramedics, nurses, midwives, and school hygienists. However, there is a lot of conflicting information on how to administer the COVID-19 vaccine. Should the skin be folded or stretched? To aspire or not?

Conclusion. Nurses have administered vaccination since many years, having proper education and experience. Nowadays available vaccines against COVID-19 are administered intramuscularly into the deltoid muscle. The recommendations say that administering of the vaccine must be performed with 90 degrees to the surface of the skin simultaneously stretching the skin with index finger and thumb, without aspiration after injection. This article presents basic information about the vaccine and the algorithm for administering the COVID-19 vaccine developed by the authors.

Key words: coronavirus, vaccine, nurse 


\section{WPROWADZENIE}

Narodowy Program Szczepień przeciw COVID-19 zakłada masowe, bezpłatne oraz dobrowolne szczepienia w celu uodpornienia społeczeństwa (w 3 etapach). Szczepienia mogą być wykonywane stacjonarnie (w placówkach POZ i innych placówkach medycznych) lub przez mobilne zespoły szczepiące czy centra szczepienne [1].

Zgodnie z Rozporządzeniem Ministra Zdrowia z dnia 27 lutego 2020 r. w sprawie zakażenia koronawirusem SARS-CoV-2, szczepienia ochronne przeciwko COVID19 mogą być przeprowadzane przez:

- osoby, które posiadają prawo wykonywania zawodu odpowiednio lekarza, felczera, pielęgniarki, położnej lub wykonują zawód ratownika medycznego;

- higienistki szkolne posiadające kwalifikacje do wykonywania szczepień określone w przepisach wydanych na podstawie art. 17 ust. 10 pkt 3 ustawy z dnia 5 grudnia 2008 r. o zapobieganiu oraz zwalczaniu zakażeń i chorób zakaźnych u ludzi” [2].

W związku z powyższym nie ma wymogów prawnych mówiących o tym, że aby pielęgniarka/położna mogła wykonać szczepienie przeciwko COVID-19 powinna posiadać dodatkowe kwalifikacje (kurs szczepień ochronnych lub specjalizację $\mathrm{w}$ dziedzinie pielęgniarstwa, w przypadku której ramowy program kształcenia podyplomowego obejmował problematykę szczepień ochronnych na podstawie przepisów o zawodach pielęgniarki i położnej.

Trwają badania nad kilkoma szczepionkami antywirusowymi przeciw COVID-19, ale aktualnie Europejska Agencja Leków dopuściła warunkowo do obrotu dwie szczepionki przeciw COVID-19 (Comirnaty - producent Pfizer/BioNTech oraz szczepionkę mRNA - producent Moderna). Są to szczepionki mRNA zawierające informacje o danym białku, natomiast nie zawierające żywego, osłabionego patogenu ani jego fragmentów. Dostarczone mRNA nie dostaje się do jądra komórkowego ani nie oddziałuje z genomem, jest niezdolne do replikacji, a jego ekspresja jest przejściowa. Jednoniciowy, informacyjny RNA (ang. messenger RNA, mRNA) jest wytworzony $\mathrm{z}$ wykorzystaniem bezkomórkowej transkrypcji in vitro na matrycy DNA, który koduje białko szczytowe (ang. spike, S) wirusa SARS-CoV-2 występujące na powierzchni cząsteczki wirusa. Białko Spike jest następnie rozpoznawane przez komórki odpornościowe jako obcy antygen. Wywołuje to odpowiedzi ze strony zarówno limfocytów T, jak i limfocytów B, prowadząc do wytworzenia przeciwciał neutralizujących, które mogą przyczyniać się do ochrony przed COVID-19. Ilość przeciwciał, jaka powstanie po podaniu 2 dawek szczepionki z mRNA daje odporność na infekcję w 95\% (Comirnaty) lub 94-95\% (Moderna). Pełna ochrona pojawia się po 7 dniach od przyjęcia 2 dawki $[3,4]$.

Preparat służy do czynnego uodparniania osób w wieku od 16 lat (Comirnaty) lub od 18 roku życia (Moderna) w celu zapobiegania chorobie COVID-19 wywołanej przez wirusa SARS-CoV-2.

Produkt leczniczy Comirnaty jest podawany domięśniowo (i.m.) po rozcieńczeniu w roztworze $9 \mathrm{mg} / \mathrm{ml}$ $(0,9 \%)$ chlorku sodu do wstrzykiwań, jako cykl 2 dawek
(0,3 ml każda) w odstępie co najmniej 21 dni. Produkt leczniczy Moderna (gotowa dyspersja - $5 \mathrm{ml}$ fiolka zawierająca 10 dawek po $0,5 \mathrm{ml}$ ) podawany jest domięśniowo (i.m.) jako cykl 2 dawek (0,5 ml każda) w odstępie 28 dni $[3,4]$.

\section{Zdarzenia niepożądane}

Bezpieczeństwo stosowania produktu leczniczego Comirnaty oceniano u osób w wieku 16 lat i starszych w 2 badaniach klinicznych, w których brało udział około 21744 uczestników, którzy otrzymali co najmniej jedną dawkę produktu leczniczego Comirnaty. W przypadku szczepionki p/COVID-19 (Moderna) w badaniu oceniono 30420 osób $w$ wieku $\geq 18$ lat, które otrzymały $\geq 1$ dawkę szczepionki mRNA-1273.

Najczęściej występującymi działaniami niepożądanymi, zazwyczaj o nasileniu łagodnym lub umiarkowanym, były (Comirnaty/Moderna):

- ból w miejscu wstrzyknięcia (80\%/92\%),

- zmęczenie $(60 \% / 70 \%)$,

- ból głowy ( 50\%/64,70\%),

- ból mięśni i dreszcze (30\%/ból mięśni 61,5\% i dreszcze $45,4 \%)$,

- ból stawów $(20 \% / 46,4 \%)$,

- gorączka i obrzęk w miejscu wstrzyknięcia (10\%/14,7\%) $[3,4]$.

Każdy preparat leczniczy (szczepionka) wymaga właściwych warunków przechowywania (temperatura 2-8 stopni Celsjusza). Świadczeniodawcy realizujący szczepienia ochronne są zobowiązani do zachowania łańcucha chłodniczego od momentu, w którym weszli w posiadanie preparatów szczepionkowych. Niezbędnym elementem wyposażenia gabinetu/punktu szczepień oprócz zestawu do udzielania pierwszej pomocy i zestawu przeciwwstrzasowego jest odpowiednio monitorowana lodówka (Tab. 1).

Tab. 1. Przechowywanie preparatów do szczepień w placówkach medycznych i ich użycie w gabinetach szczepiennych [3]

\begin{tabular}{|c|c|}
\hline $\begin{array}{l}\text { Realizacja szczepień } \\
\text { w gabinecie, w którym } \\
\text { znajduję się lodówka } \\
\text { stacjonarna lub lodówka } \\
\text { transportowa, bez stałego } \\
\text { elektronicznego } \\
\text { monitoringu temperatury. }\end{array}$ & $\begin{array}{l}\text { - } \quad \text { kontrola temperatury w lodówce,nie } \\
\text { rzadziej niż } 1 \text { raz na } 2 \text { godziny, poprzez } \\
\text { umieszczenie w niej termometru ręcznego. } \\
\text { - } \quad \text { odnotowanie każdego pomiaru } \\
\text { temperatury na liście kontrolnej: } \\
\text { „kontrola temperatury lodówki” } \\
\text { - zapewnienie odpowiedniej wydajność } \\
\text { chłodzenia i użyteczność szczepionek } \\
\text { poprzez zastosowanie schłodzonego } \\
\text { (niemrożone) wkładu i unikanie jego } \\
\text { bezpośredniego kontaktu z fiolką. } \\
\text { niezużyta i nierozcieńczona fiolka, po } \\
\text { zakończonej pracy punktu szczepień, } \\
\text { zostaje ponownie umieszczona w lodówce } \\
\text { ze stałym monitoringiem temperatury. }\end{array}$ \\
\hline \multicolumn{2}{|c|}{$\begin{array}{l}\text { Nieużyte (nierozcieńczone) fiolki z jednej lodówki do drugiej powinny } \\
\text { być transportowane za pomocą torby termoizolacyjnej lub lodówki } \\
\text { transportowej, w taki sposób, aby zachować ciąg chłodniczy. }\end{array}$} \\
\hline $\begin{array}{l}\text { Realizacja szczepień } \\
\text { w gabinecie, } \\
\text { na wyposażeniu którego } \\
\text { nie ma lodówki. }\end{array}$ & $\begin{array}{l}\text { - po rozcieńczeniu preparatu do szczepienia } \\
\text { może być on przechowywany w } \\
\text { temperaturze } 2-30 \text { stopni C, przez } 6 \mathrm{~h} \text {. }\end{array}$ \\
\hline
\end{tabular}


Kwalifikacja do szczepienia przeciw COVID-19 jest dokonywana na podstawie wypełnionego przez pacjenta kwestionariusza wstępnego wywiadu przesiewowego (zawierającego 8 pytań wstępnych, 10 pytań dotyczących stanu zdrowia i oświadczenia o wyrażeniu dobrowolnej zgody na szczepienie p/COVID-19) i badania lekarskiego [5].

Przygotowanie preparatu Comirnaty (zgodnie z zasadami aseptyki i antyseptyki):

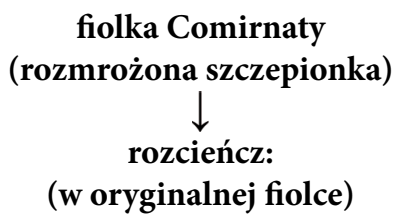

- dodaj $1,8 \mathrm{ml} 9 \mathrm{mg} / \mathrm{ml}(0,9 \%)$ roztworu chlorku sodu do wstrzykiwań

(używając igły o grubości 21 G lub cieńszej)

- pobierz z fiolki 1,8 ml powietrza do pustej strzykawki po rozcieńczalniku

(wyrównanie ciśnienia w fiolce przed wyjęciem igły z korka fiolki)

- odwróć fiolkę z rozcieńczoną dyspersją 10 razy

(delikatnie, nie wstrząsaj)

- umieść na fiolce datę i godz. przydatności szczepionki (6 h od sporządzenia)

gotowa fiolka Comirnaty

(zawiera $2,25 \mathrm{ml}=6^{\star}$ dawek po $0,3 \mathrm{ml}$ ) [3].

\section{* UWAGA!}

- po rozcieńczeniu możliwe jest pobranie sześciu dawek z fiolki, jeśli do wszystkich dawek używane są strzykawki i/albo igły o małej martwej objętości ( $\leq 35 \mathrm{ul}$ ),

- jeśli objętość szczepionki pozostająca w fiolce nie wystarcza na pełną szóstą dawkę $(0,3 \mathrm{ml})$, należy wyrzucić fiolkę oraz jej zawartość,

- nie należy zbierać zawartości z wielu fiolek w celu przygotowania dodatkowej dawki $[3,6]$.

Algorytm wykonania szczepienia (i.m., iniektio intramuscularis) przeciw Covid-19 (szczepionką Comirnaty):

sprawdź zlecenie lekarskie i wypełnioną przez pacjenta kartę kwalifikacji do szczepienia

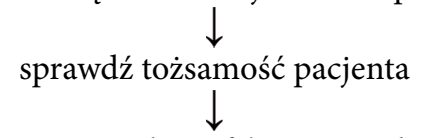

umyj higienicznie i zdezynfekuj ręce/załóż maseczkę ochronną

$$
\text { przygotuj zestaw do wykonania iniekcji: }
$$

- w przypadku przygotowanej wcześniej (zgodnie $\mathrm{z}$,algorytmem przygotowania pojedynczej dawki do szczepienia przeciwko Covid) pojedynczej dawki szczepionki: przygotowana (opisana datą i godz. przydatności szczepionki) w jałowej strzykawce pojedyncza dawka szczepionki, igła do szczepienia $25 \mathrm{~mm}$ - 38mm, gazik nasączony preparatem antyseptycznym lub preparat antyseptyczny w spray-u, rękawiczki jednorazowego użytku, plaster ochronny, pojemnik twardościenny na igły (biohazard), worek na odpady medyczne zakaźne i niezakaźne, maseczka chirurgiczna.

- w przypadku braku wcześniej przygotowanej pojedynczej dawki szczepionki: strzykawka do mieszania (2 ml lub $5 \mathrm{ml}$ ), strzykawka ze zintegrowaną igłą $16 \mathrm{~mm}$, igła do szczepienia $25 \mathrm{~mm}-38 \mathrm{~mm}$, sól fizjologiczna, gazik nasączony preparatem antyseptycznym lub preparat antyseptyczny w spray-u, plaster ochronny, rękawiczki jednorazowego użytku, pojemnik twardościenny na igły (biohazard), worek na odpady medyczne zakaźne i niezakaźne.

przygotuj preparat do podania w sposób aseptyczny

( jednej fiolki należy przygotować 6 gotowych do podania dawek szczepionki i umieścić je w oznaczonym pojemniku (tacy), zapisując datę i godzinę otwarcia fiolki; do każdej strzykawki należy nabrać $0,3 \mathrm{ml}$ przygotowanego zgodnie $\mathrm{z}$, algorytmem przygotowania szczepionki Comirnaty" preparatu; każda pojedyncza dawka powinna zostać opisana datą i godziną jej przydatności).

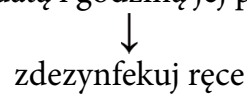

(do dezynfekcji rąk zaleca się użycie preparatów antyseptycznych alkoholowych w postaci płynnej)

nałóż rękawiczki jednorazowego użytku (włożenie rękawiczek nie jest obligatoryjne, ale wskazane $\mathrm{z}$ uwagi na bezpieczeństwo osoby wykonującej szczepienie - istnieje możliwość kontaktu z potencjalnie zakaźnymi płynami ustrojowymi osoby szczepionej)

ułóż pacjenta w wygodnej pozycji siedzącej lub leżącej (u pacjentów ze skłonnością do omdleń)

$$
\text { wyznacz miejsce iniekcji }
$$

(szczepionkę Comirnaty należy podać w mięsień naramienny - na wysokości dwóch - trzech palców poniżej wyrostka barkowego łopatki)

oceń wzrokowo i palpacyjnie wyznaczone miejsce iniekcji

(pod kątem przeciwwskazań)

zdezynfekuj miejsce wykonania iniekcji preparatem antyseptycznym z odległości ok. $15 \mathrm{~cm}$ lub użyj gotowego gazika nasączonego preparatem antyseptycznym

(w przypadku użycia preparatu antyseptycznego w spray-u odczekaj wskazany przez producenta czas, przed wykonaniem szczepienia)

$$
\text { wykonaj iniekcję: }
$$

- ułóż swoją dłoń na barku szczepionego pacjenta, ostrożnie przytrzymaj i rozciagnij pomiędzy kciukiem a palcem wskazującym okolice, w którą będzie wykonywane wstrzyknięcie (u osób bardzo wychudzonych 
należy ująć skórę w fałd i lekko odciągnąć, tak aby igła nie oparła się na kości!),

- uprzedź pacjenta o momencie wkłucia,

- zdecydowanym ruchem, ręką dominującą wprowadź 3/4 długości igły (nie należy wprowadzać całej długości do nasadki ze względu na ryzyko złamania igły) do tkanki mięśniowej prostopadle (pod kątem 90 ${ }^{\circ}$ ) do powierzchni skóry (igła do podania szczepionki Comirnaty powinna zostać dobrana w zależności od masy ciała i płci pacjenta*),

- wstrzykuj preparat powoli, tak aby nie spowodować bólu (nie zaleca się aspiracji; jest ona niepotrzebna przy wykonaniu wkłucia w mięsień naramienny, gdyż nie przebiega w jego okolicy żadne większe naczynie krwionośne, a przedłuża zabieg oraz zwiększa bolesność i ryzyko mechanicznego uszkodzenia barku

lub złamania igły w tkankach) $[7,8,9,10]$

obserwuj pacjenta i utrzymuj z nim kontakt słowny usuń igłę z tkanki

(przytrzymując nasadkę igły, jednostajnym szybkim ruchem energicznie)

(nie pocieraj miejsca wkłucia)

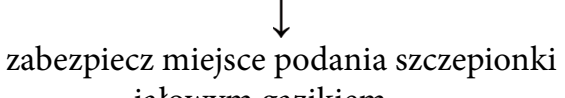
jałowym gazikiem

(w razie wykonywania szczepienia u osoby przyjmującej leki przeciwzakrzepowe należy zastosować mocny ucisk miejsca wstrzyknięcia przez co najmniej 2 minuty (nie rozcierać); należy poinformować pacjenta o ryzyku powstania krwiaka)

$$
\downarrow
$$

wyrzuć igłę do pojemnika twardościennego

(zaczepiając igłę o pojemnik)

strzykawkę do worka na odpady medyczne

$$
\downarrow
$$

zdejmij rękawiczki jednorazowego użytku

(umieść je w worku na odpady medyczne)

uporządkuj materiał, sprzęt i otoczenie<smiles>[AlH2]</smiles>

higienicznie umyj ręce/zdezynfekuj ręce

(do dezynfekcji rąk zaleca się użycie preparatów antyseptycznych alkoholowych w postaci płynnej)

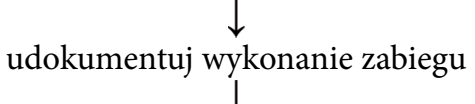

poinformuj pacjenta o konieczności pozostania na terenie placówki medycznej przez przynajmniej

15 minut po wykonaniu szczepienia

(30 minut w przypadku pacjentów, u których $\mathrm{w}$ wywiadzie wystąpiła natychmiastowa reakcja alergiczna o dowolnym nasileniu na szczepionkę

lub lek parenteralny oraz osoby, u których w wywiadzie wystąiła anafilaksja z jakiejkolwiek przyczyny)

(obserwuj pacjenta pod kątem wystąpienia omdlenia

lub anafilaksji po wykonanym szczepieniu)

* Rekomendacje długości igieł, w zależności od masy ciała pacjenta (Tab. 2):

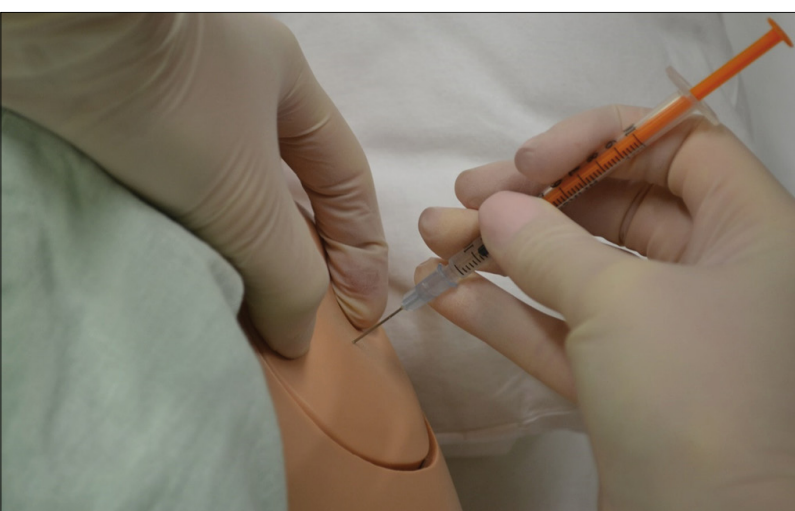

Ryc 1. Technika podania szczepionki p/COVID-19 i.m. (rozciągnięcie skóry i uchwycenie strzykawki z igłą)

- $<60 \mathrm{~kg}-25 \mathrm{~mm}$,

- $60-90 \mathrm{~kg}-25-38 \mathrm{~mm}$,

- $>90-38 \mathrm{~mm}$.

W razie wykonywania szczepienia u osoby przyjmującej leki przeciwzakrzepowe należy użyć cienkiej igły $\leq 0,6(\geq 23 \mathrm{G})$.

\begin{tabular}{|c|c|c|}
\hline dorośli & \multirow{2}{*}{ długość igły } & \multirow{2}{*}{ miejsce wstrzyknięcia } \\
\hline płeć, masa ciała & & \\
\hline mężczyźni i kobiety <60 kg & $25 \mathrm{~mm} *$ & mięsień naramienny \\
\hline kobiety 60-90 kg & $25-38 \mathrm{~mm}$ & mięsień naramienny \\
\hline kobiety $>90 \mathrm{~kg}$ & \multirow{2}{*}{$38 \mathrm{~mm}$} & \multirow{2}{*}{ mięsień naramienny } \\
\hline mężczyźni > 118 kg & & \\
\hline
\end{tabular}

Tab. 2. Długości igieł używanych do szczepienia i.m. [11]

Źródło: Needle length and injection site of intramuscular injections. Reproduced from Morbidity and Mortality Weekly Report, 2006; 55 (RR-15): 1-48; Centers for Disease Control and Prevention [11]

\section{PODSUMOWANIE}

Masowe szczepienia przeciw COVID-19 są szansą na powrót do normalnej rzeczywistości i funkcjonowania społeczeństw na całym świecie. Szczepienia w Polsce rozpoczęły się dnia 27 grudnia 2020 roku. Według danych Ministerstwa Zdrowia aktualnie zostało zaszczepionych 410480 tysięcy osób (na dzień 15.01.2021r.) [12], co według portalu statystycznego Our World in Data stanowi niewiele ponad $1 \%$ zaszczepionych (11 pozycja Polski na świecie).

Niezmiernie ważnym aspektem bezpieczeństwa i prawidłowego wchłaniania i działania szczepionki, oprócz dystrybucji, przechowywania oraz kwalifikacji pacjenta do szczepienia, jest technika wykonania szczepienia.

Przedstawiony algorytm wykonania szczepienia drogą domięśniową (i.m.) ujednolica zasady przygotowania i podania dostępnej w Polsce szczepionki przeciw COVID-19.

\section{ORCID}

Marzena Jaciubek (iD) https://orcid.org/0000-0002-1277-0518 Karolina Prasek (D) https://orcid.org/0000-0002-9338-7165 


\section{PIŚMIENNICTWO}

1. Narodowy Program Szczepień https://www.gov.pl/web/szczepimysie/narodowyprogram-szczepien-przeciw-covid-19 (dostęp 06.01.2021)

2. Rozporządzenie Ministra Zdrowia z dnia 27 lutego 2020 r. w sprawie zakażenia koronawirusem SARS-CoV-2.

3. Charakterystyka produktu leczniczego Comirnaty https://www.fda.gov/ media/144413/download?utm_medium=email\&utm_source=govdelivery (dostęp 06.01.2021)

4. Charakterystyka produktu leczniczego Moderna https://www.fda.gov/ media/144637/download (dostęp 10.01.2021)

5. Kwestionariusz wstępnego wywiadu przesiewowego przed szczepieniem osoby dorosłej przeciw COVID-19 https://szczepienia.pzh.gov.pl/wp-content/ uploads/2020/12/kwestionariusz_szczepienia_z_oswiadczeniem.pdf (dostęp 06.01.2021)

6. Czajka H. Podstawowe zasady wykonywania szczepień ochronnych https:// www.mp.pl/szczepienia/praktyka/porocedury/71176,podstawowe-zasadywykonywania-szczepien-ochronnych (dostęp 06.01.2021)

7. Matkowska-Kocjan A. Co zrobić, jeśli w trakcie wykonywania szczepienia w igle pojawi się krew? https://www.mp.pl/szczepienia/ekspert/technika_organizacja_ szczepien/151264,unikanie-aspiracji-przy-podawaniu-szczepionek?fbclid=IwAR 2JxHH0s3j6Q392NZIXFprwLa-9TxyEnDCO_7aDQwbq95cV17BYw1lmudg (dostęp 15.01.2021)

8. Kroger AT, Sumaya CV, Pickering LK, et al. General recommendations on immunization. Recommendations of the Advisory Committee on Immunization Practices (ACIP). Morbidity and Mortality Weekly Report, 2011; 60 (RR-02): 1-60

9. Sepah Y, Samad L, Altaf A, et al. Aspiration in injections: should we continue or abandon the practice? F1000 Research, 2017; 3 .

10. Taddio A, McMurtry CM, Shah V, et al. Reducing pain during vaccine injections: clinical practice guideline. CMAJ, 2015; 187: 975-982.

11. Ogólne wytyczne dotyczące szczepień ochronnych. Zalecenia Amerykańskiego Komitetu Doradczego ds. Szczepień Ochronnych (ACIP). Med. Prakt. Pediatr., WS 1/2009 (na podstawie: General Recommendations on Immunization: Recommendations of the Advisory Committee on Immunization Practices. MMWR 2006; 55 (RR 15): 1-48.

12. Rządowa strona dotycząca szczepień i całego procesu https://www.gov.pl/web/ szczepimysie (dostęp 15.01.2021).
Praca zgłoszona do czasopisma: 23.01.2021

Praca zaakceptowana do druku: 27.01.2021 